\title{
Politics of Compliance in Global Infectious Disease Control: Cases of SARS Control in China
}

\author{
Victor Chi-Ming Chan \\ Department of General Education, Hang Seng Management College \\ Hang Shin Link, Siu Lek Yuen, Shatin, Hong Kong SAR, China \\ Tel: 852-39635108Ｅ-mail: victorchan@hsmc.edu.hk
}

Accepted: March 1, 2014

doi:10.5296/ jpag.v4i1.5452 URL: http://dx.doi.org/10.5296/ jpag.v4i1.5452

\begin{abstract}
This paper examines China's compliance decisions of global infectious disease control in the cases of Severe Respiratory Acute Syndrome (SARS). The processes involve interactions of actors in various levels such as states, sub-state actors, and international actors. Although all states share the interests of a disease-free world, the consequences of national compliance on disease control processes are always costly and political. Why does a state comply with international standards mainly issued by World Health Organization (WHO) on infectious disease control? The paper looks into the politics of global infectious disease control by investigating the processes of China's compliance decisions regarding SARS. More importantly, the paper addresses the political implications of compliance politics for China's on global health crises.
\end{abstract}

Keywords: Compliance action, infectious disease control, SARS, China 


\section{Introduction}

Global infectious disease control is of our shared interest in which contains and eradicates potential epidemic outbreaks across the world. In the past decades, the World Health Organization (WHO) contributed to rally, organize, and implement international initiatives against the spread of infectious diseases. But the total number of deaths caused by infectious diseases remains high, particularly in developing countries (WHO, 2002). Fidler (1996) notes that "scientists and public health experts identify emerging and re-emerging infectious diseases as great public health threats facing humanity" (p. 5) in both developed and developing countries. The WHO has portrayed infectious disease as a crisis for the entire world (WHO, 1996, p. 105). So, what goes wrong in the process of global infectious disease control?

This paper addresses a significant refinement on the concept of infectious disease control. Its nature is a combination of routine public health practices and management of public health emergency. Its scope is not only focusing on national boundary but also global arena. Its critical junctures are categorized into three arenas namely information disclosure, institutional coordination, and social mobilization. So, the central question of the paper is how sovereign states together with sub-state stakeholders determine to what extent and in what circumstances they choose to comply with international norms and initiatives particularly set by the WHO in three critical junctures. The paper examines China's compliance politics by illustrating the processes of containing SARS. China as an authoritarian state but a growing power in the world was expected to adopt a responsible and transparent approach for SARS containment. However, the Chinese public health governance system in the early SARS outbreak failed to comply with the WHO's guidelines which led to massive contagions all over the world in early outbreak period. The compliance politics of SARS in fact represented a conflict between sovereignty and globalization. Domestic political consideration and calculation alone was no longer enough to meet the challenges of a globalized health crisis. In the course of SARS containment, the paper revealed a remarkable transformation of China's compliance politics with substantial improvement in information disclosure, containment coordination, and social mobilization. Rapid and determined governance responses after late April 2003 enhanced the process of disease eradication. The paper concludes by discussing the implications of compliance politics in China.

\section{Re-conceptualizating Infectious Disease Control: Nature, Scope and Critical Junctures}

\subsection{Nature: moving away from routine-crisis dichotomy to a comprehensive decision making process}

The nature of infectious disease control raises the question of whether it is generally a routine practice or a crisis response. Routine practices of infectious disease control include daily disease surveillance, regular promotion of sanitization/infection control, overseeing infection controls in public areas such as hospitals and schools, and coordinating laboratory research with different collaborated partner institutions (Leonard \& Howitt, 2007). Traditionally, it 
requires a relatively hierarchical structure to run the services, but new public management (NPM) reforms since the late 1980s have been refining infectious disease control by a more flexible structure steered by national health authority while also featuring collaboration among various local actors including mass media and non-governmental organizations (NGOs). Crisis responses of infectious disease control include quick and appropriate decisions and full implementation of various measures within a national boundary (Boin, 2008) in order to encounter a usual situation (Hermann, 1972, p. 13) which is full of time pressure and uncertainty (Rosenthal, Hart \& Charles, 1989, p. 10). It usually requires a small but centralized unit in the government to avoid information distortion, make prompt as well as proper decisions, and supervise other collaborated forces (Smart \& Vertinsky, 1977; Rosenthal, Hart \& Charles, 1989). Nevertheless, such a dichotomy only reflects a partial condition. In fact, both are needed for making suitable and comprehensive decisions in order to contain the spread of infectious diseases depending on the severity of as well as the knowledge about the outbreaks. To be more accurate, it is essential for decision makers with a combined mentality with routine practice and crisis response towards infectious disease control in our highly vulnerable and globalized world.

\subsection{Scope: A Globalized Response}

The scope of infectious disease control is significantly extended because of the impacts of unchallenged globalization. Globalization is always expressed in the context of economics like international trade, multinational corporations, and rapid advancement of telecommunication and in terms of culture like homogeneity of living style in different cosmopolis (Holm \& Sorensen, 1995, p. 4). This also brings about a well connected network of research institutions and even individual medical professionals such as the Global Outbreak Alert and Response Network (GOARN) under the WHO which benefits the overall wellbeing of global public health. However, globalization in the realm of decision making processes of infectious disease control gradually challenges the authority of nation states and probably empowers non-state actors such as the WHO and civil society organizations to generate more appropriate choices so as to fulfill global interests (Reinicke, Witte \& Martin, 2000, p. 81; Dodgson, Lee \& Drager, 2002).

\subsection{Critical Junctures}

The essential time periods of infectious disease control in this paper are called critical junctures. They are those defining moments or breaking points within the course of making critical decisions which are under immense time pressure and uncertainties. In the case of acute infectious disease control, three critical junctures can be identified and discussed as follows.

Critical juncture 1: declaration delay. It is important for an infectious disease affected nation to grasp the crisis. Although it is not realistic to expect that a nation especially early on would be able to fully recognize the outbreak of a contagion, the longer time it needs to do that, the greater the possibility of severe delays in effective responses and of eventually deepened and worsened the impacts of the crisis. So, what is the key element in this critical juncture? Typically, decision-making processes in the early outbreak of infectious disease follow the 
normal surveillance mechanism suggested by the legal and administrative framework of routine infectious disease control. However, an acute infectious disease outbreak requires crisis responses and transnational cooperation (Prescott, 2007). Such requirement depends on whether governments can receive sufficient information from the frontier agencies like hospitals or laboratories or other non-state actors if applicable to make sense of the seriousness of the outbreak (Boin, Hart, Stern \& Sundlius, 2005, p. 10-11).

Critical juncture 2: containment coordination. The second critical juncture is national containment efforts for infectious disease control. Such efforts usually begin after public notification when the national government, particularly Ministry of Health (MOH), takes initiatives to coordinate efforts to prepare and implement disease control plans. The effectiveness of the plans and actions depends largely on the capability of the government organs. So, higher level of inter-ministerial coordination may be necessary to achieve further success in infectious disease control. In other words, it is imperative to examine how and when a national government determines to adopt hospital infection control and possible quarantine measures and the extent to which they comply with those recommended by the WHO advice and guidelines.

Critical juncture 3: social participation. The third and final juncture is social participation, through which a national government can sufficiently and effectively mobilize and crystallize the supports of social actors against infectious disease control. It can widen participation by releasing suitable types and amounts of information for containment preparation, by inviting social leaders to involve direct or indirect decision making processes.

\section{Politics of Compliance: A Theoretical Overview}

\subsection{Defining Compliance}

In the last decade, due to the increasing importance of international organizations (Chayes \& Chayes, 1995), there has been extensive scholarly work about how a sovereign state works on complying with various kinds of international agreements (Haas 2000; Fature \& Lefevere, 1999; Bilder, 2000). Various scholars have contributed extensively to define or analyze the concept of compliance. Kingsbury (1997) mentions a conventional and shared concept of compliance "as conformity of behavior with legal rules" (p. 49). Similarly, Mitchell (1995) defines compliance "as an actor's behavior that conforms to a treaty's explicit rules" (p. 5). Jacobson and Weiss (1998) argue "compliance refers to whether countries in fact adhere to the provision of the accord and to the implementing measures that they have constituted" ( $p$. 1) which in fact does not specify the nature of the accord. Haas (1997) also defines a state's compliance as "actual behavioral change in the direction of international injunction". Chan (2006) argues that compliance is how much effort a sovereign state makes to implement and enforce the agreement made internationally. The above definitions of compliance share a common component-actual policy adjustment including implementation and enforcement-which allows the international community to observe to what extent a sovereign state turns its commitment into actual policies explicitly. In other words, compliance may be observed how a sovereign state implemented to address the actual changes of policy, laws, organizational routines and practices (Haas 1997, 2000). One 
disputed component of the definitions is however related to the changing nature of international agreements-binding or non-binding instruments for national compliance. Traditionally, it has been believed that "countries comply much better and more fully with binding internationally agreements than with non-binding instruments" (Weiss, 1997, p. 1) because sovereign states always spend most of the time to look for a binding treaty through different rounds of diplomatic negotiations. If any sovereign state member fails to comply, it may be settled via international court of justice or other internationally recognized legal institution. However, the binding instruments over-emphasize the dominant roles of sovereign states. There are considerable violations among member states against binding legal instruments (Raustiala \& Slaughter, 2002) and therefore the overall effectiveness of the binding instruments is in doubt. In addition, it is more difficult to reach a compromise of a binding international agreement particularly when the number of treaty parties (sovereign states) has been dramatically increased to 192 since the end of the Cold War. More importantly, in terms of rapid movement of capital, ideas, and people, the impact of current globalization and interdependence on the international system has increasingly been marked by (1) the gradual decline of state authority and (2) the rise of non-state actors. Such conditions bring about further difficulty for negotiating an international binding legal instrument unless a multi-level approach is completely adopted (Fidler, 1999).

Then, it is essential to look for an alternative-non-binding instrument, i.e. soft law. According to Weiss (1997), they "can be negotiated more quickly than treaties, can involve parties other than states, can express shared values, can respond quickly to new problems that are not yet well understood, and provide actors with flexibility in responding to issues" ( $p$. 2-3). More rising non-state actors can be involved because "compliance with soft law must be seen as a dynamic, interactive process involving many different actors, public and private, at many different levels: international, national, and local" (p. 3). The forms of soft law include declarations, resolutions, codes of conduct, recommendations, advices, guidelines, and decisions of international bodies.

The concept of compliance in this paper is defined as actual or explicit actions taken by individual states to accommodate international rules, standards or norms with respect to infectious disease control. It particularly refers to how disease affected countries decided to fulfill the guidelines on case detection, surveillance, and management suggested by the WHO. Two main concerns are identified from the above definition: (1) explicating the importance of non-binding instruments like guidelines and standards for respective disease control and (2) determining how to implement compliance.

\subsection{Explaining Compliance Politics: Bringing a Capable State Back}

The paper introduces a framework of compliance politics to explain the control of epidemic, considering several different critical junctures. This framework adopts the principles of good governance, including emphasis on the wider participation of various levels of actors in making decisions and carrying out implementation (Rosenau 1992). Compliance politics comprises five main components-(1) a capable national government for public health emergency/crisis; (2) sub-national government organs; (3) mass media roles in information 
inputs and disclosure; (4) responses from civil society; and (5) international assistance and cooperation (Yu, 2007, p. 50). The interactions between national government and sub-national government organs/mass media/civil society/international organizations strongly influence how a national government perceives, understands, and handles an emergency or a crisis.

From state denial to a capable national government. Under the impacts of contemporary globalization since the 1990s, attention has been increasingly paid to the hypothesis of state denial. There are many forms of state denial such as the "loss of national authority", "the powerlessness of government in the face of global capital", or "the obsolescence of the nation-state as an organizing principle" (Weiss, 1998). From an economic perspective, Ohmae (1995) argues, "nation-states are no longer meaningful units, in which to think about economic activity..... In a borderless economy, the units that make sense are......region state(s)" (p. 32). Castells (1997) also argues that "state control is increasingly bypassed by increasingly global flows of capital, goods, services, technology, communication, and information" (p. 243). The authority of sovereign state declines rapidly when a single sovereign state alone is in fact no longer managing its problems smoothly, even though those the problems occasionally occurred at local level. It is largely due to the geographical borders having been blurred already. So, a local problem may turn into a transboundary crisis.

In spite of the rising importance of non-state actors and the relatively diminished power of sovereign states in managing policy problems, the state remains the key actor in crisis governance. Although the state is no longer as dominant as it once was, it will not simply disappear from the world, particularly at the time of a crisis. So our main question is: How do we position the role of state?

It is essential to begin with the core arguments of Weiss's (1998) The Myth of Powerless State. She re-emphasizes that it is unworkable to follow the assumption of a unitary state. In addition, she accurately points out that state denial has misjudged what really happens to sovereign states. The declining role of sovereign state is not equal to an overall diminution of the state. On the contrary, it is necessary to look into the capability of a sovereign state, which is essential for meeting the challenges of globalized problems.

In order to manage a crisis like SARS properly, a capable government needs to ensure (1) accurate and sufficient information gathering, (2) flexible institutional restructuring for managing crises, and (3) mobilizing social participation for support (Boin, Hart, Stern \& Sundelius, 2005). Built on these objectives as premises, this paper suggests that a strong political linkage between a national government and non-state actors is very important to contain a public health crisis.

Information gathering. How does a national government receive accurate and sufficient information which is useful for deciding suitable responses? Undoubtedly, the information gathering organs in national government serve an important role to provide as much information as possible to decision makers. Apart from national government itself, however, this dissertation considers at least four alternative types of information providers. 
First, state-sponsored or state-based sub-national organizations like local governments and public medical institutions. They are under the hierarchical structure and by law subordinated to national government. For example, in China's infectious disease law prior to SARS outbreak, sub-national organs including local health authorities or local hospitals are subject to report what is happening in their areas. Hospital infection in a local area easily demonstrates how important sub-national actors are in a disease outbreak because they have the first-hand and accurate information. However, the collaboration of reporting among these actors is not always as smooth as it might be expected or hoped. Delay in reporting is sometimes found and can even lead to disastrous consequences.

Second, mass media is an important intermediary channeling information between national government and society. From the point of view of government, the reports made by mass media may to some extent reflect the thoughts of the general public. More importantly, thanks to mass media, news reports or exclusive news provide the national government unofficial information about the updates of the crisis. Mass media is therefore much more important particularly when the sub-national organs attempt to block the information reporting to national level, as was the case with SARS control in China in early February and early April 2003 (Guo, 2003).

Third, civil society organizations are another important information source particularly when the national government wants to have better and accurate understanding of the general public because they are the ones which have direct contacts with their service targets. Since mass media may not be as neutral as we expect due to political and commercial reasons, various civil society organizations can at times directly channel their opinion and information directly to national government.

Fourth and finally, due to the forces of uncertainty and cross-boundary reality, even a capable government alone cannot manage the crisis very well and therefore requires the assistance of international counterparts. In the cases of the SARS crisis, it is essential to recognize how much time was utilized to activate communications between national health authorities and the WHO and the time used by $\mathrm{MOH}$ to make formal responses to the WHO requests, regardless what decisions $\mathrm{MOH}$ had made. In addition, it is important to look into whether the national authority receives or provides any technical or financial assistance from or to international community.

Flexible institutional restructuring. Crisis generates time pressures and uncertainty as mentioned earlier (Boin, Hart, Stern \& Sundelius, 2005). Under a crisis condition, routine and standardized procedures used in daily practices do not work very well to meet the needs, because of the differences in policy goals and constraints. The national government needs to consider whether an emergency or ad hoc mechanism is required to lead the entire process of decision making process. A capable central government therefore has to show its ability as a government to adjust the structure of governing (Pierre \& Peters, 2000) in order to adapt to the governance challenges arising from the crisis. It includes creating or abolishing government organs so as to increase the efficiency of the entire policy decision and implementation processes (Yu, 2007). For example, it may be necessary to promptly set up an 
ad hoc inter-ministerial coordination committee or specialized decision making unit headed by senior officials to oversee the control processes against a transboundary or cross-sectoral crisis. It needs to be very clear, for all levels of governments and medical institutions, who are in charge and who are responsible for carrying out control measures (Guo, 2003). In the case of a public health emergency, which department(s) at such specific level should be responsible for steering and implementing entire processes such as surveillance, reporting, and preparing guidelines for case management? If there is no a single department, including $\mathrm{MOH}$, able to conduct the above duties, it is more necessary to establish ad hoc government organs to oversee the entire processes.

Mobilizing social participation. The implementation of control measures against a crisis cannot be effective unless the grassroots tolerate, understand and support them (Yu, 2007). So an important task of a capable government is to rally and organize NGOs and the general public at the time of crisis decision making. There are three ways of mobilizing social participation. First, it is imperative to release suitable and essential information particularly during the early outbreak of a crisis to social organizations which are able to assist in recruiting additional human and financial resources. Second, a capable government should be able to recruit social leaders to involve or give advice in decision making process. Third, a capable government utilizes media and private sector to enhance the implementation of compliance decisions. Media serves as an educator and promoter of government measures to lessen public fears. Private sector provides additional resources to carry out what the government has decided. In the case of infectious disease control, hospital infection and quarantine were two main policy initiatives which caused public misunderstanding and also required substantial amounts of personal protective equipment. So, by providing correct information regarding SARS control, mass media could abate the worries of the general public while the private sector could assist the government to look for the cheapest way to get or even produce the sufficient amounts of needed equipment.

Compliance decisions and actions. Compliance decisions become important actions taken by sovereign states for achieving infectious disease control in our globalized world. It relates to those non-binding instruments-the WHO advice and guidelines related to SARS detection, surveillance, and management. Before the WHO official notification, the WHO had already begun its mission to provide assistance to suspected disease affected nations. Different requests for information and site visits had been made to China during SARS epidemics. How did they determine to accept and cooperate or deny and ignore these WHO request? This is one type of compliance decision.

Another type of compliance decisions is how member states, particularly those affected by infectious diseases, adjust domestic practices, standards, and regulations to comply with the WHO guidelines and recommendations. It includes domestic decisions regarding to the WHO principles of information transparency-when the government should make public notification of epidemic outbreak. In addition, it can examine to what extent newly developed domestic guidelines reflect the WHO recommendations. 


\section{Macrothink

\section{SARS and China's Compliance Politics}

\subsection{Overview of SARS in China}

SARS is commonly regarded as the first global epidemic in the 21 st century, one that affected more than 28 countries and territories in the world (WHO, 2003). Although national or international efforts were implemented to look for the nature of SARS virus, medical professionals initially could not figure out that the etiologic agent of SARS was a novel and emerging coronavirus (Wang \& $\mathrm{Wu}, 2003$ ). It eventually led to not only massive hospital infection outbreaks and community spread but also a global epidemic.

Tracing back the SARS cases, the majority of new infections were caused by close contacts of patients including family members, healthcare workers, and other patients who were not protected with contact or respiratory precautions. So, the SARS CoV can be spread by direct contact with droplets and indirect contact through fomites, respiratory equipment, clothing etc (CDC, 2003; Seto, Tsang \& Yung, 2003).

The first case of SARS was confirmed on 16 November 2002 in Foshan, Guangdong. The epidemic eventually was contained, as certified on 24 June 2003 by the official announcement of the WHO. The silent invasion of the SARS virus caused about 5,327 people to become infected, and 349 people died (WPRO WHO, 2006).

Figure 1 shows China's reported SARS cases, by date of report, from November 2002 to July 2003. The information gap between February 2003 and March 2003 was attributed to cover-ups by officials. When the information was allowed to flow freely, the reported cases increased substantially. In late May 2003, SARS transmission declined sharply and there were no new cases after early June.

Figure 1

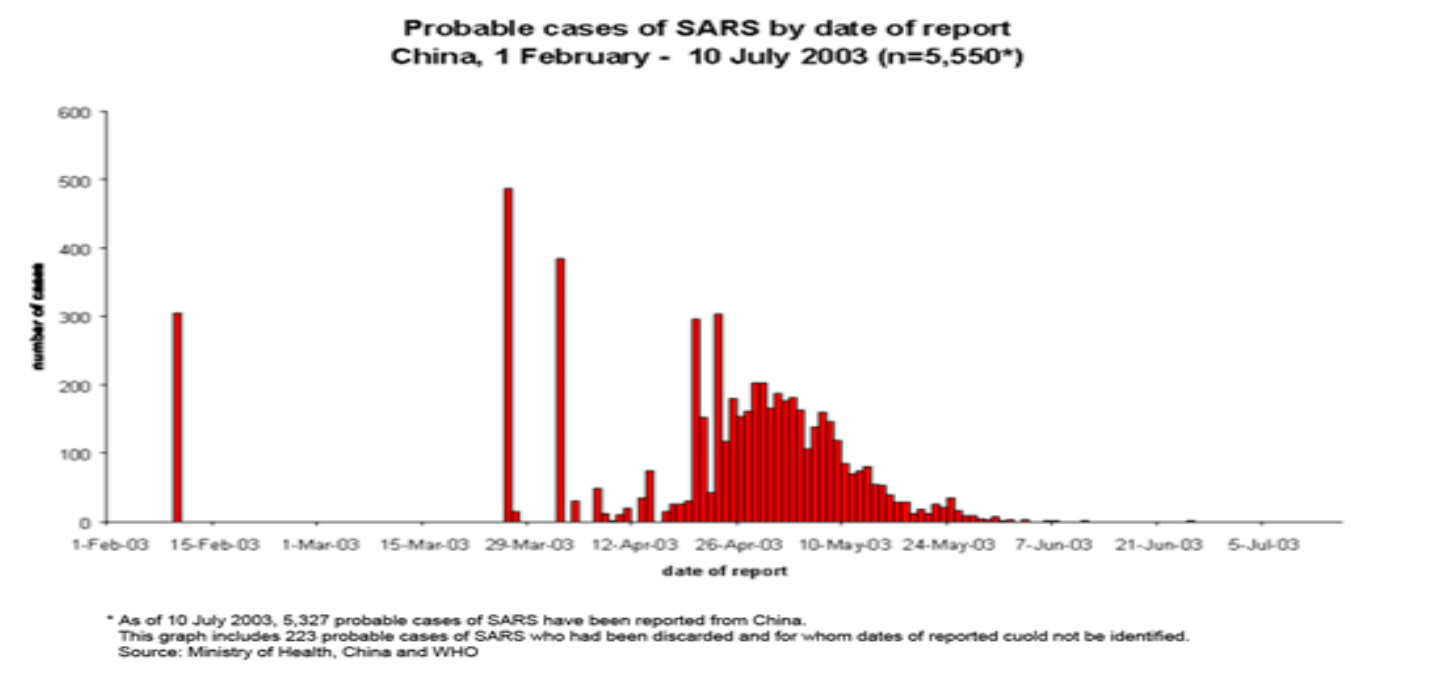

Source: WHO (2003) http://www.who.int/csr/sarsepicurve/epiindex/en/index3.html (Accessed on 10/5/2010) 


\subsection{Critical Junctures and Compliance Politics of SARS in China}

Critical juncture 1 and China's delayed notification. The first critical juncture involves when and how the Chinese government recognized the seriousness of the SARS crisis and openly updated the seriousness of SARS to the rest of the world. If we trace back the epidemic, the first case of SARS appeared in Foshan on 16 November 2002, following which the Chinese government took almost three months before eventually making public notification on 11 February 2003 at a Guangdong provincial press conference. Therefore China faced major domestic and foreign criticisms for its cover-up of information about the disease's spread, which led to a global contagion in the first half of 2003 (Cao 2004; Song \& Zhang 2004; Ho, 2003). Did the Chinese government intend to hide this information? Or did the Chinese government really not have accurate information about what was really happening in Guangdong during the early SARS outbreak, a situation which would have obstructed and misled its decision-making regarding public notification? Regarding this juncture, we consider how the Chinese government gathered information regarding the disease outbreak and how and why such process depended heavily on the provincial (Guangdong) level. Central government organs such as the $\mathrm{MOH}$ and China CDC were very passive about information regarding the strange disease and about reporting it to the rest of the country.

At provincial level, the government did take several measures to look into the disease and lessen public panic. The provincial government knew there were outbreaks of atypical pneumonia in various Guangdong cities such as Foshan, Heyuan, Zhongshan, and Guangzhou in late December 2002 and therefore decided to send various teams to Heyuan and Zhongshan in order to investigate the disease and look into its medical treatment in early January 2003 (He, 2003). In addition, the Guangdong provincial government issued a document entitled Investigation Reports of Pneumonia Cases of Unknown Cause in Zhongshan and sent it to health bureaus and medical institutions at the province level and above in late January 2003 (WPRO WHO, 2006). In addition, the Vice Minister of the MOH took a team to Guangdong on 9 February 2003.

It seemed that the central government, at least the $\mathrm{MOH}$, had been notified of the outbreak. However, no positive compliance decisions regarding public notification were made until 11 February 2003. However, the flow of Investigation Reports somehow was "blocked" by the Chinese New Year holidays together with suppression of provincial media and ignoring the WHO inquiry of unofficial information. Medical institutions like hospitals and even China CDC did not receive Investigation Reports immediately, a situation which probably accelerated the spread of atypical pneumonia (Abraham, 2004).

Suppressing mass media did not lessen public panic. On the contrary, the tight control of information dissemination did not prevent public panic and in fact worsened the entire progress of disease control. Ordinary people could still use text messages to update information regarding the conditions in Guangdong, even though no coverage related to infectious disease could be found in the mass media (He, 2004; He, 2003).

Due to limited information transmission and blocked upward reporting, the first juncture of SARS control in China was highly influenced by the actions and inaction of provincial 
governments, resulting in delays in the visits of expert teams including those from the WHO and further delays in preparing the first infection control guidelines during the SARS crisis.

Critical juncture 2: national containment coordination. The second critical juncture, national containment efforts, began when the Chinese national government first sent a national expert team to investigate a strange disease outbreak in early January 2003. It took more than 6 months to complete national containment, which WHO officially announced on 24 June 2003 when it declared that Beijing, the last region in mainland China in the WHO list of affected areas, was "SARS-free". Our consideration of this juncture focuses on when and how the central government of China determined appropriate measures in terms of hospital infection control and quarantine measures in China, appropriate specifically with regard to the advice and recommendations of the WHO. It is imperative in this juncture to describe the restructuring process of the original institutional setting and the establishment of new ad hoc crisis-related organs for multi-level containment coordination at China's national level. MOH-WHO interactions in China from 12 February 2003 to 27 February 2003 are summarized in Table 2 below. Clearly, the $\mathrm{MOH}$ responses to WHO advice and requests had direct impacts on national decision making regarding appropriate SARS control actions that would have been in compliance with WHO advice and recommendations and international expectations. The overall responses were very negative. The $\mathrm{MOH}$ denied two information requests by the WHO China Office in February 2003. The MOH's reply again expressed appreciation for the WHO's concern but insisted that the Guangdong outbreak was under control. In addition, the MOH offered limited permission for the expert team that WHO requested visit Beijing, Fujian, and Guangzhou; the $\mathrm{MOH}$ only allowed the team to visit Beijing.

Table 2: MOH-WHO interactions in China from 12 February 2003 to 27 February 2003

\begin{tabular}{|c|c|c|c|}
\hline Perioc & & WHO & $\mathrm{MOH}$, China \\
\hline $\begin{array}{l}\text { Feb } \\
2003 \\
\text { Feb } \\
2003 \\
\end{array}$ & & $\begin{array}{l}\text { WHO, in writing, requests that the } \\
\text { MOH provide epidemiological } \\
\text { information and offers the WHO's } \\
\text { assistance }\end{array}$ & $\begin{array}{l}\text { The MOH informs the WHO that the } \\
\text { Guangdong outbreak is under control. The } \\
\text { MOH states the source of the virus may not } \\
\text { be in Guangdong. }\end{array}$ \\
\hline $\begin{array}{l}\text { Feb } \\
2003\end{array}$ & 20 , & $\begin{array}{l}\text { Regional Director of the WHO } \\
\text { Pacific Regional Office calls the } \\
\text { MOH to request permission for a } \\
\text { WHO team to investigate the } \\
\text { Guangdong outbreak }\end{array}$ & $\begin{array}{l}\text { The } \mathrm{MOH} \text { does not permit this immediately } \\
\text { and requests the WHO in writing to develop } \\
\text { terms of reference for the investigation } \\
\text { team, specifying its members, the timing of } \\
\text { visits and the places to be visited. }\end{array}$ \\
\hline $\begin{array}{l}\text { Feb } \\
2003 \\
\text { Feb }\end{array}$ & & $\begin{array}{l}\text { The WHO faxes the necessary } \\
\text { documents to the MOH and proposes } \\
\text { a visit to Beijing, Fuilian and }\end{array}$ & $\begin{array}{l}\text { The MOH only allows the team to visit } \\
\text { Beijing. }\end{array}$ \\
\hline 2003 & & Guangdong & $\begin{array}{l}\text { Laboratory tests are arranged to test whether } \\
\text { Chlamydia is the causal agent. But, the } \\
\text { finding is not publicized and the WHO is not } \\
\text { informed. }\end{array}$ \\
\hline
\end{tabular}

Source: WPRO WHO, (2006) 
Worse still, the year of 2003 was a crucial year of China's politics because the fourth generation of leaders was going to take over at lianghui in March 2003 (Fewsmith, 2003). It made for a political near-vacuum in March when the newly formed leadership was still not able to master the overall condition (Bo, 2007).

Between mid-February and early April, two official SARS news reports were released, assuring people that Guangdong and Beijing were safe. The first report was published in People's Daily on 19 March 2003, under the title "The Minister of Health Meets WHO representative: the Atypical Pneumonia in Guangdong is Under Control". The details of the report emphasized that the $\mathrm{MOH}$ fully understood the origin of disease, had responded rapidly to the epidemic in Guangdong, and that the situation was under control. Minister of Health Zhang Wenkang stated clearly that most of the patients had recovered and the life of disease affected areas had got back to normal. The second official report was released on 26 March 2003 by Xinhua News Agency. It reported that the Beijing Municipal Government was able to successfully control the epidemic contagion in Beijing.

More importantly, the reports mentioned above showed that the central government and particularly the $\mathrm{MOH}$ had begun to take back the coordination of actions for SARS containment in late March 2003. The meeting between the MOH and the WHO served as a breakthrough for further cooperation, but their interactions, as shown in Table 3 below, indicated that the $\mathrm{MOH}$ compliance decisions regarding the WHO requests remained quite unstable and complicated until late April 2003.

Table 3 MOH-WHO interactions from 4 March 2003 to 27 March 2003

\begin{tabular}{|c|c|c|}
\hline Periods & WHO & $\mathrm{MOH}$, China \\
\hline $\begin{array}{l}\text { Mar 4, } \\
2003-\text { Mar } \\
15,2003\end{array}$ & $\begin{array}{l}\text { The WHO team meets at the China } \\
\text { CDC and receives medical } \\
\text { information from various affected } \\
\text { regions. } \\
\text { The WHO expresses its concern } \\
\text { regarding the cover-up problem } \\
\text { related to the exact number of } \\
\text { SARS cases. }\end{array}$ & $\begin{array}{l}\text { The } \mathrm{MOH} \text { again insists on Chlamydia as a } \\
\text { possible cause. Later, when Beijing } \\
\text { scientists reveal the new virus; they no } \\
\text { longer mention Chlamydia. } \\
\text { The Health Minister agrees to a WHO } \\
\text { mission to help find the cause of the } \\
\text { Guangdong outbreak. }\end{array}$ \\
\hline $\begin{array}{l}\text { Mar 23, } \\
2003-\text { Mar } \\
27,2003\end{array}$ & $\begin{array}{l}\text { The WHO requests a visit to } \\
\text { Guangdong and other areas. }\end{array}$ & No agreement is reached. \\
\hline
\end{tabular}

Source: WPRO WHO, (2006)

Up until early April 2003, containment coordination at national level began, with frequent appearances of national leaders such as Hu Jintao and Wen Jiabao on television to comment on SARS containment, followed by a series of institutional restructurings. The most critical point was April 20 when Health Minister Zhang Wenkang and Beijing Mayor Men Xuenong were sacked for their mismanagement of national and Beijing SARS control (DeLisle, 2003). 
$\mathrm{Wu}$ Yi, Vice Premier and leader of the Inter-ministerial committee on SARS, became the Health Minister. Later, the committee was upgraded to "SARS combat headquarters" and she became its Commander. It consisted of 11 teams/offices to support the development of and decision making within a comprehensive SARS containment plan. The ad hoc institution against SARS virus was completely established with the leadership of high rank officials. Such institutional restructuring demonstrated the process of centralizing SARS containment efforts in the hands of core national leaders. Despite an over-decentralized administrative system of a highly political nature, SARS containment became a truly national agenda and SARS-related measures at the national level were determined and then implemented centrally and down to the provinces, regions and periphery.

More national initiatives, actions generally in compliance with the WHO advice and recommendations, were proposed, approved, and implemented beginning in late April 2003. For example, Table 4 lists the major guidelines for SARS management in a medical setting. Some of them were revised on the basis of the updated WHO guidelines published on 11 April 2003 and 1 May 2003.

Table 4 Major guidelines for SARS management in China after 20 April 2003

\begin{tabular}{|l|l|}
\hline $\begin{array}{l}\text { Date } \\
\text { release }\end{array}$ & of \\
\hline 3-MAY-03 & $\begin{array}{l}\text { Recommendations for treatment and discharge arrangement on SARS suspect } \\
\text { and probable cases (revised) }\end{array}$ \\
\hline 3-MAY-03 & $\begin{array}{l}\text { Emergency notice on transportation arrangement of SARS patients and suspect } \\
\text { SARS patients to different locations }\end{array}$ \\
\hline 4-MAY-03 & Guidance on infection control in SARS designated hospitals \\
\hline 5-MAY-03 & $\begin{array}{l}\text { Supplementary Note on Recommendations for treatment and discharge } \\
\text { arrangement on SARS suspect and probable cases (revised) }\end{array}$ \\
\hline
\end{tabular}

Source: China PLA Health Section (2003)

In short, this critical juncture was long and complicated in terms of decision making on SARS control actions, including actions which were the subject of WHO guidance and advice. Provincially and district-led crisis coordination alone proved not to be very effective when the virus spread all over the nation. Response delays in March 2003 were politically driven matters, while the quick responses later in April and in May and June were largely attributed to the emergence at the national level of increasingly centralized crisis coordination.

Critical juncture 3: social mobilization. Our analysis of the third critical juncture looks into how the Chinese government was able to mobilize and rally support from non-state actors so that they could in return work and follow up on SARS control decisions and actions, most of which by that time were in compliance with WHO advice and guidance. Tracing back the SARS control efforts, the real attempt for national government to mobilize non-state actors began in early April. It had taken around 3 months to enter this juncture. There had in fact been many obstacles that blocked social participation at various times during the SARS crisis. It is essential for us to describe how the governments, both central and local, were able to recognize and act upon the importance of societal actors in executing SARS control actions. 
In the beginning, the most important obstacles were information barriers imposed by the governments. In an earlier section, the paper discussed how mass media could not perform its role as an information provider, which in return impeded positive decisions regarding public notification. Another obstacle was the bureaucratic mentality with regard to social participation. The officials did not consider social actors to be important players in public policy, particularly in a crisis situation. Instead of being viewed as a positive force, social mobilization might be viewed by officials as a potential destructive element that could endanger social stability. They thought it was better not to invoke social participation because it might get out of control. Officials relied much more on "expert" advice, but very little, or not at all, on opinions from social organizations.

Suppression of social participation during the first five months of SARS control could not really limit awareness and concern, but in fact escalated the panic among the general public. It is very likely that such suppression was due to the decentralized nature of Chinese political system. The situation shifted to allow more social participation in early April 2003 when non-state actors like Dr. Jiang Yanyong began to speak out. Then, the national government recognized the impact of social participation in lessening public worries, along with current updates on SARS as well as the implementation of WHO-compliant SARS control measures and later on renaming the anti-SARS campaign the "People's War on SARS". Local governments invited NGOs to become involved in the anti-SARS campaign in April 2003. Although the purpose of mobilizing social participation in the above situation was very instrumental, it demonstrates that to a very great extent the officials needed the help of NGOs which had better relationships with community members. It was very important, particularly when harsh measures were implemented on them.

The roles and status of NGOs in the SARS containment processes were highly recognized in May 2003. Two counseling hotlines run by the psychologists of Peking University, Tsinghua University, and Peking Polytechnic University and other voluntary hotline associations.

Schwartz \& Evans (2007) emphasize the importance of NGOs in SARS containment. They list a number of NGO efforts in China to contain SARS. In Shanxi, an association for women endorsed and implemented SARS containment programmes related to health education through seminars and workshops. One of the core NGOs in China-The China Association for NGO Cooperation - ran an education program in Henan for students of high schools and primary schools in order to increase their knowledge of SARS prevention and treatment. The progress mentioned in the above reflected that even an authoritarian state would still need to work along with civil society in encountering a multi-level crisis.

In short, mobilizing social participation in China's SARS control involved dramatic changes. Government's attitudes shifted from ignorance to support, which in turn facilitated the implementation of SARS control decisions in compliance with WHO advice and guidance. 


\section{Implications of Compliance Politics in China's SARS Epidemic Crisis: Legitimatizing the Authoritarian Regime}

Based on the SARS control experiences in China, the paper argues that SARS crisis was not only a catastrophic public health event but also an important opportunity for them to strengthen the credibility and legitimacy of their rule. The section is going to describe how China utilized its relationships with other actors during a crisis situation like SARS as a tactic to achieve a prolonged and legitimate an authoritarian regime. It is then followed by examining how compliance decisions for managing the SARS crisis can be important means for China to gain international recognition in a globalized world.

\subsection{SARS Epidemic Crisis as an Opportunity to Legitimize Authoritarian Rule}

Legitimacy crisis of socialist regime in China. First, there is no constant "check and balance" on the performance of authoritarian governments because there is the persistence of one party dictatorship but no free and open election. Under a socialist regime led by China Communist Party (CCP), even though there are periodic and more competitive elections, the general public still does not have fair and free choices (Fewsmith, 2008). The CCP remain enjoying the unchallenged position in the existing political system. Second, due to the absence of political challenges, authoritarian governments look to enlarge their perceived legitimacy by focusing on economic development. In the past decades, the Chinese government adopted market economic reforms since 1978. Market liberalization undoubtedly has been bringing about persistent increase in GDP and the living standard (Fewsmith, 2008). However, economic achievements may not persistently appear particularly when the national economies are highly interdependent due to financial globalization. Economic downturn can simply erode the expectation of and legitimacy of the authoritarian government. It may even lead to some cases in which local officials exaggerate the GDP figure in order to keep the state's annual economic growth estimates (Wang, 2003). Third, bureaucracy in authoritarian governments is commonly regarded as less efficient than those in democracies due to lack of sense of responsibility (Frederickson \& Smith, 2002). Local authorities in China for example delayed the reporting of SARS outbreak simply because of their own personal interests.

Crisis but an opportunity. Crisis becomes a political and administrative challenge to government capability. In normal operation, bureaucracy is intended to focus on departmental or organizational interests. The outbreak of a crisis offers an important opportunity to rethink the operation of government machinery. It may be an exceptional chance to integrate major government organs and form a more centralized coordination unit to study and contain the crisis. Moreover, when the general public focuses on the crisis and government performance in dealing with the crisis, they may forget about the problems they have been facing in poor economic conditions. The newly formed fourth generation leadership under Hu Jintao and Wen Jibao assumed its duties in March 2003. SARS crisis turned out to be a great chance for $\mathrm{Hu}$ and Wen to consolidate their power bases. For them, SARS was not a pure public health challenge but a way to strengthen the legitimacy of new leadership (Freedman, 2005; Bo, 2007). 
Compliance politics at stake. Even though an authoritarian government intentionally turns the current crisis as a platform to show off how efficient it is in the course of crisis management, the concern here is how to ensure a way for authoritarian government to successfully contain the crisis and then gain whatever it intends to in terms of credibility and legitimacy? Being a capable government is the appropriate answer. The capability of a government as an important element of compliance politics determined the effectiveness of the crisis control efforts. So, the important point here is how does a government maintain a stable or cooperative relationship with non-state actors? Or to be more accurate, how is an authoritarian government able to utilize social actors to support its crisis control policies which strengthen the credibility and legitimacy of the existing authoritarian rule. China's tactic on SARS control particularly during the early contagion was a nearly complete cut off from other actors. The reliance on traditional authority seemed not to be sufficient to handle a contemporary crisis which was transboundary both within China (across provinces) and internationally. The shift in mid-April fortunately produced extensive effect on stopping SARS contagion which as a result enhanced the legitimacy of the newly elected national leaders.

\subsection{Compliance Actions and the International Recognition of Authoritarian Legitimization}

In order to sustain its rule, an authoritarian government depends not only on both domestic support but also international recognition. So, how does the international community view the authoritarian rule? One of the main qualities is the degrees of compliance (Haas 2000).As a responsible member in the international community, higher compliance level of the agreed principles or recommendations are greatly respected regardless of the nature of the political systems. When compliance is a commonly accepted action, non-compliance action will be certainly a non-ethical and even a harmful act on international community. In the case of China's SARS crisis, the Chinese government did not tell the truth about the SARS updates. Then, international community began to criticize China's misconducts even though public notification of SARS was not necessary in accordance with the requirements of IHR (1969). More and more criticisms from different countries particularly from western side were sent to condemn the Chinese government in the early SARS spread (Chi, 2003). Even SARS was labeled as a Chinese disease (Guo, 2003) which meant that China was a 'trouble maker' of global health. However, the Chinese government headed by Hu Jintao and Wen Jiabao committed to SARS control in April 2003 particularly participating in international SARS meetings to explain the situations in China (Chi, 2003). The significant shift of the Chinese government in prioritizing international participation gained worldwide recognition.

Although it is true that the ideological debate on democracy remains fierce among western and non-western countries, the top priority of international community in a crisis situation is to provide enormous joint efforts against the crisis effectively and efficiently. It is highly expected that to a certain extent the national governments actively participate internationally. More importantly, serving as a responsible member of international community not only increases international status but also strengthens and consolidates domestic support because the general public is proud of governmental efforts for crisis governance (Chi, 2003). 


\section{Conclusion}

The paper emphasizes the essential of compliance politics of SARS control in China. Even though China remains a one-party dominance authoritarian state, the emergence of compliance politics which emphasizes the interactions between a capable national government and other stakeholders to a very large extent has brought a more legitimized regime domestically and internationally More importantly, democratic as well as good governance elements have already added into the policymaking processes. With more information releases, flexible organizational structure, and wider social participation, it is expected that China would adopt compliance strategy in managing global affairs. However, global public health crises remain an imperative governance challenge particularly for the new generation of leadership in 2012.

\section{References}

Abraham, T. (2004). Twenty-first century plague: the story of SARS. Hong Kong: Hong Kong University Press.

Bilder, R. B. (2000). Beyond compliance: helping nations cooperate. In D. Shelton (ed.) Commitment and compliance: the role of non-binding norms in the international legal system (67-73). Oxford: Oxford University Press.

Bo, Z. (2007). China's elite politics: political transition and power balancing. Singapore: World Scientific.

Boin, A., Hart, P. 't, Stern, E. \& Sundelius, B. (2005). The politics of crisis management: public leadership under pressure. Cambridge, UK: Cambridge University Press.

Boin, A. (2008). Editor's introduction: fundamentals of crisis development and crisis management: an introduction to critical crisis readings. In A. Boin (xvii-xxxvii) (ed.) Crisis management (Volume I), London: Sage.

Cao, C. (2004). SARS: "Waterloo" of Chinese science. China: an international journal 2(2), 262-286.

Castells, M. (1997). The power of identity. Malden, Mass: Blackwell

CDC. (2003) Infection control precaution for aerosol-generating procedures on patients who have suspected severe acute respiratory syndrome (SARS) Retrieved from http://www.cdc.gov/ncidod/sars/aerosolinfectioncontrol.htm (accessed on 20 April 2007).

Chayes, A. \& Chayes, A. H. (1995). The new sovereignty: compliance with international regulatory agreements. Cambridge: Harvard University Press.

Chi, F. L. (2003). Jing zeng: Zhongguo - SARS weiji yu zhidu biange (Alarm: China - SARS crisis and system reform). Beijing: Minzhu yu jianshe chubanshe (Democracy Building Publication).

China PLA Health Section (2003). Chuanranxing feidianxing feiyan fangzhi peixun jiaocai (SARS: training materials for prevention and control). Beijing: People's Military Medical 
Press.

DeLisle, J. (2003). SARS, greater China, and the pathologies of globalization and transition. Orbis 47(4), 587-604.

Dodgson, R, Lee, K. \& Drager, N.( 2002). Global health governance: a conceptual review. Discussion paper 1, London: centre on global change and health, London school of hygiene $\&$ tropical medicine and world health organization.

Downs, G. W., Rocke, D. \& Barsoom, P. (1996). Is the good news about compliance good news about cooperation? International organization, 50, 3, 379-406.

Fature, M. \& Lefevere, J. (1999). Compliance with international environmental agreement. In N. J. Vig \& R. S. Axelrod (eds.) The global environment: institution, law, and policy (141-144), Washington DC: congressional quarterly.

Fewsmith, J. (2003). China and the politics of SARS. Current history 102(605): 250-255.

Fewsmith, J. (2008). China since Tiananmen: from Deng to Hu Jintao. New York: Cambridge University Press.

Fidler, D. P. (1996). Globalization, international law, and emerging infectious disease, Emerging infectious diseases. 77.

Fidler, D. P. (1999). International law and infectious diseases. Oxford: Clarendon Press.

Frederickson, H. G. \& Smith, K. B. (2002). The public administration theory primer, Colorado: Westview Press.

Freedman, A. (2005). SARS and regime legitimacy in China. Asian affairs, Vol. XXXVI (2): 169-180.

Guo, Y. (2003). SARS weiji dui Zhongguo zhili jiegou de yingxiang (Impacts of SARS crisis on China's governance structure). In A. G. Hu (ed.) Toushi SARS: jiankang yu fazhan (Exploring SARS: Health and Development), 265-287, Beijing: Tsinghua University Press.

Haas, P. M. (1997). Why comply, or some hypotheses in search of an analyst. In E. B. Weiss (ed.) International compliance with nonbinding accords, (21-48). Washington D.C.: American society of international law.

Haas, P. M. (2000). Choosing to comply: theorizing from international relations and comparative politics. In D. Shelton (ed.) Commitment and compliance: the role of non-binding norms in the international legal system, (43-64). New York: Oxford University Press.

He, B. (2004). SARS and freedom of the press: has the Chinese government learnt a lesson? In J. Wong and Y. Zheng (eds.) The SARS epidemic: challenges to China's crisis management (181-198). Singapore: World Scientific.

He, L. (2003) SARS: kaohe Zhongguo (SARS: a test on China). Beijing: People's Publication. 


\section{I Macrothink}

Journal of Public Administration and Governance ISSN 2161-7104 2014, Vol. 4, No. 1

Henkin, L. (1979). How nations behave: law and foreign policy (2nd edition). New York: published for the council on foreign relations by Columbia University Press.

Hermann, C. F. (1972). International crises: insight from behavioral research. New York: The Free Press.

Ho, K. L. (2003) Shared responsibilities, unshared power: the politics of policy-making in Singapore. Singapore: Eastern Universities Press.

Holm, H. H. \& Sorensen, G. (1995). Whose world order? Uneven globalization and the end of the Cold War. Boulder: Westview Press

Jacobson, H. K. \& Weiss, E. B. (1998). A framework of analysis. In E. B. Weiss \& H. K. Jacobson (eds.) Engaging countries: strengthening compliance with international environmental accord (1-18). Cambridge, Mass: MIT Press.

Kingsbury, B. (1997). The concept of compliance as a function of competing conceptions of law. In E. B. Weiss (ed.) International compliance with non-binding accords (49-80). Washington, DC: American Society of International Law.

Leonard, H. B. \& Howitt, A. M. (2007). Against desperate peril: high performance in emergency preparation and response. In D. E. Gibbons (ed.) Communicable crises: prevention, responses, and recovery in the global arena (1-25). Charlotte: Information Age Publication.

Mitchell, R. B. (1995). Compliance theory: an overview. In J. Cameron (ed.) Improving compliance with international environmental law (3-28). London: Earthscan Publications.

Ohmae, K. (1995). The end of the nation state: the rise of regional economies. New York: Free Press.

Pierre, J. \& Peters, B. G. (2000). Governance, politics and the states. NY: Macmillan Press Ltd.

Prescott, E. M. (2007). The politics of disease: governance and emerging infection. Global health governance 1(1) Retrieved from http://dipomacy.shu.edu/academics/global_health (Accessed on June 12, 2007)

Raustiala, K. \& Slaughter, A. (2002). International law, international relations and compliance. In W. Carlsnaes, T. Risse, and B. A. Simmons (eds.) Handbook of international relations (538-558). London, Thousand Oaks; New Delhi: Sage Publication.

Reinicke, W. H., Witte, \& Martin, J. (2000). Global public policy: the role of non-binding international legal accords. In D. Shelton (ed.) Compliance with nonbinding international legal accords: a challenge to international law, (75-99). Oxford; New York: Oxford University Press

Rosenau, J. N. (1992). Governance, order and change in world politics. In Governance without government: order and change in world politics 1-29. Cambridge: Cambridge University Press. 
Rosenthal, U., Hart, P. 't. \& Charles, M. T. (1989). The world of crises and crisis management. In U. Rosenthal, M. T. Charles and P. 't Hart (eds.) Coping with crises: the management of disasters, riots, and terrorism (3-33). Springfield: Charles Thomas.

Seto, W. H, Tsang, D. \& Yung, R. et al (2003). Effectiveness of precautions against droplets and contact in prevention of nosocomial transmission of severe acute respiratory syndrome (SARS). Lancet 361:1519-20.

Smart, C. \& Vertinsky, I. (1977). Designs for crisis decision units. Administrative science quarterly, 22:640-657.

Song, L. \& Zhang T. (2004) Tupo SARS chongwai: Weiji de yingdui yu chul (Breakthrough from SARS: crisis responses and management). Beijing: Scientific and Technical Documents Publishing House.

Weiss E. B. (1997). Introduction. In E. B. Weiss (ed.) International compliance with non-binding accords (1-20). Washington D.C.: American Society of International Law.

Weiss, L. (1998). The myth of the powerless state. New York: Cornell University Press.

Wang, L. \& Wu, S. H. (2003). SARS bingyuanxue (SARS pathology). In L. Zheng (ed.) SARS yu tufa gonggong weisheng shijian yingdui celue (SARS and public health emergency responses) (1-5). Beijing: Kexue chubanshe (Science publication).

Wang, Z. (2003). Zhongguo gonggong weisheng de Weiji yu zhuangji (China's public health: crisis and opportunity). In A. Hu (ed.) Tou shi SARS: jian kang yu da zhang (Exploring SARS: health and development) (156-189) Beijing: Tsinghua University Press.

Western Pacific Regional Office, WHO. (2006). SARS: how a global epidemic was stopped. Geneva: World Health Organization.

World Health Organization (1996). World health report 1996. Geneva: WHO.

World Health Organization (2002). WHO report on infectious diseases. Online at http://www.who.int/infectious-disease-report/2002/pdfversion/Ch0Introduction.pdf (June 25, 2005)

World Health Organization. (2003). Severe acute respiratory syndrome (SARS): status of the outbreak and lessons for the immediate future, Online at: http://www.who.int/csr/media/sars_wha.pdf (June 23, 2005)

Yu, X. (2007) Fei chuantong anquan yu gonggong weiji zhili (Non-traditional security and public crisis governance). Zhejiang: Zhejiang University Press.

\section{Copyright Disclaimer}

Copyright reserved by the author(s).

This article is an open-access article distributed under the terms and conditions of the Creative Commons Attribution license (http://creativecommons.org/licenses/by/3.0/). 